evaluated biochemically whether neuroleptics block complex I in human brain tissue. The neuroleptics studied significantly inhibited complex I in human brain tissue. The concentration of haloperidol required for half-maximal inhibition of the enzyme activity of complex I ( IC $\left._{50}\right)$ was 25 times lower than the required concentration of clozapine, and 4 times lower than that of chloropromazine. There were no significant effects of the neuroleptics on complex II and III, and on complex IV at similar drug concentrations.

The selectivity of the inhibition of respiratory chain complexes by neuroleptic drugs paralleled that induced by MPTP toxicity which leaves complexes II to IV unaffected. Furthermore, the extent of inhibition of enzyme activity parallels the incidence of extrapyramidal side-effects induced by classical $v$. the atypical neuroleptics as determined in clinical studies. The results of our study therefore support the hypothesis that extrapyramidal sideeffects in humans may be the result of neurotoxicity due to oxidative damage induced by neuroleptics.

The development of tardive dyskinesias during chronic treatment with neuroleptics is often explained by the striatal dopamine receptor supersensitivity hypothesis. However, there is evidence that protracted pharmacological side-effects are not due to sustained dopamine receptor blockade. Our hypothesis is consistent with both the agedependency of tardive dyskinesia and the higher incidence of tardive dyskinesia in patients with subtle organic changes (Pourcher et al, 1995). It has recently been established that with increasing age mitochondrial DNA damage increases in brain tissue (Linnane et al, 1989; Corral-Debrinski et al, 1992). Inhibition of the respiratory chain complexes induced by neuroleptics may act together with mitochondrial DNA damage due to increasing age or a preexisting reduction in oxidation due to brain lesions and further reduce oxidative phosphorylation. When a critical threshold is exceeded clinical symptoms might appear, as is established in other mitochondrial diseases.

If the antipsychotic effect and the unwanted extrapyramidal side-effects are indeed unrelated properties of neuroleptics, new principles might be applied in the development of new neuroleptics. Neuroleptics that do not damage mitochondrial respiratory chain enzyme complexes might represent a potentially important clinical advance of great benefit to the patient.

Burkhardt, C., Kelly, J. P., Lim, Y.-H., et al (1993) Neuroleptic medications inhibit complex I of the electron transport chain Annals of Neurology, 33, 512-517.
Corral-Debrinski, M., Horton, T., LotT, M. T. et al (1992) Mitochondrial DNA deletions in human brain: regional variability and increase with advanced age. Nature Genet, 2, 324-329.

Linnane, A. W., Marzuki, S., OzaWa, T., et al (1989) Mitochondrial DNA mutations as an important contributor to ageing and degenerative diseases. Lancet, 3, 642-645.

Pourcher, E., BARUCH, P., Bouchard, R. H., et al (1995)

Neuroleptic associated tardive dyskinesias in young people with psychoses. British Journal of Psychiatry, 166, 768-772.

SCHAPRA, A. H. V. (1994) Evidence for mitochondrial dysfunction in Parkinson's disease - a critical appraisal. Movement Disorders, 9, 125-138.

I. MAURER

S. ZIERZ

H.-J. MöLLER

University of Bonn

F. JERUSALEM

53105 Bonn, Germany

\section{Case reports and confidentiality}

SIR: Professor Dimond's analysis (1995) appears superficial. She asserts, although without providing any supporting evidence by way of reported cases or quotations from authoritative text books, such as are normally found in legal opinions, that a breach of confidence would exist "if the patient could legitimately be identified by him/herself" as well as by others from reading a case report in a scientific journal such as the British Journal of Psychiatry.

A breach of confidence exists when confidential information about an identifiable individual is disclosed without proper authority. It may be legally compensatable if committed by someone who owes a duty of confidentiality to the individual concerned, and if other legal criteria are satisfied.

It is not easy to see how any breach of confidentiality could be involved in the disclosure of information about an individual to that individual himself.

The chances of anyone other than the patient himself, or a psychiatrist acquainted with him, being able to identify a patient from the sort of anonymised descriptions customarily published in psychiatric journals seem small, except perhaps in a few very unusual cases, and the chances of an action for breach of confidentiality following such an event yet more remote.

In the unlikely event of proceedings for breach of confidentiality, the plaintiff would, one imagines, need to show that he had actually been identified by at least one person other than himself, as a result of reading the report, not merely that there was a chance that that might happen. 
However, were the judge to allow the plaintiff to argue his case on the basis merely of risk of identification, the door would be open to argument about the degree of risk that the patient might be identified as a result of reading the report. Hence such matters as the nature and extent of the readership of the publication, and its availability, would be relevant.

Professor Dimond also asserts, ambiguously, that "any attempts to justify disclosure on the basis of public interest would not be supported by the decision in W. v. Egdell". That case, however, concerned circumstances of an entirely different character and is of doubtful relevance to the issue under discussion. It seems far from certain that a judge, in a case in which reasonable care had been taken to anonymise the personal details in a case report published in a professional journal and read almost exclusively by other professionals in the field, in which there was no wanton or gratuitous disclosure of personal information such as would enable the generality of readers to identify the individual concerned, and in which it could be argued that there was a scientific value to the publication, which would be eroded by further distortion and falsification of the personal information provided, might not rule publication justified in the public interest.

Even were such an action to succeed, the damages would probably be nugatory.

It is entirely reasonable for authors to discuss proposed case reports with the patient concerned, if the patient's condition is such that he is able to engage in a sensible conversation on the matter, but the requirement that consent be obtained from the patient in every instance is absurdly over-sensitive and, as Professor Russell, Dr Healey and Professor Marks all point out in the same editorial, likely to inhibit publication of potentially valuable reports.

Many millions of case reports must have been published in the medical literature without, so far as I am aware, a single action for breach of confidence having followed. Certainly Professor Dimond quotes none. May I suggest a second opinion?

Wilkinson, G., FAhy, T., Russell, G., et al (1995) Case reports and confidentiality. British Journal of Psychiatry, 166, 555-558.

\section{Friar Gate}

I. G. BRONKS

Derby DEI IBY

AUTHOR's REPLY: The subject of the law on confidentiality is complex and I am sorry that my attempts to simplify were regarded as superficial. My short paper arose from a request by a psychia- trist who had published a case study which had been recognised by the subject of the case study (a doctor). Identification (by changing personal details) had not been prevented on the grounds that if details were changed, then case studies could not be compared for the purposes of medical education. Nor had the patient's consent been obtained to the publication. The question I was asked was "Is this a breach of confidentiality?" My response was "yes".

Difficulties arise from a lack of decided cases of statute provision and also from the fact that the duty arises from several sources.

1. If the action of the patient is based on the duty of care owed in the law of negligence, then harm must be established for the action to succeed and in that case, compensation might be negligible. In such a case it would have to be established that another person recognised the patient's identity, since that would be how harm occurred. A case where this action was recognised is the New Zealand case of Fitchett $v$. Furness (1958). Dr Bronks appears to be concerned only with this right of action.

2. There has been recognition in a recent case (1988) that there is a legal duty to keep information which has been passed on in confidence, confidential, even when there is no pre-existing relationship or legally enforceable contract between the parties. This arises from the law of equity. An injunction would be obtainable to prevent a disclosure which was in breach of this duty (Mason \& McCall Smith, 1967).

3. There is also a professional duty, recognised by most Codes of Professional Practice and Ethics, to keep confidential information about the patient unless consent is given to the disclosure by the patient or there is a recognised legal duty to disclose. Here, unlike the law of negligence, the misconduct lies in the disclosure rather than in any harm which could or has occurred. A report to the registration body about a breach of the Code of Professional Practice and Ethics may also be possible (Finch, 1994), and could result in the practitioner's suspension or erasure from the Register.

4. In addition there may be a term in the contract of employment for employees to keep confidential, information about a patient (subject to recognised exceptions). This duty is enforceable by the employer through disciplinary proceedings and thus the hospital or employed doctor is in a different situation than the self-employed practitioner. This contractual duty exists irrespective of any harm which occurs.

I then explored the possibility that publication of a case study from which the patient could be identified was justified under one of the recognised 